\title{
Progress on the Study of the Anti-Tumor Effect of Emodin
}

\author{
Xiulan Yang1 ${ }^{*}$, Jiaoyuan Qin² \\ ${ }^{1}$ Department of Pharmacology, Basic Medical School of Yangtze University, Jingzhou, China \\ ${ }^{2}$ Department of Medicine, Yangtze University, Jingzhou, China \\ Email: *406490115@qq.com
}

How to cite this paper: Yang, X.L. and Qin, J.Y. (2021) Progress on the Study of the Anti-Tumor Effect of Emodin. Journal of Biosciences and Medicines, 9, 207-218. https://doi.org/10.4236/jbm.2021.97019

Received: June 24, 2021

Accepted: July 19, 2021

Published: July 22, 2021

Copyright (c) 2021 by author(s) and Scientific Research Publishing Inc. This work is licensed under the Creative Commons Attribution International License (CC BY 4.0).

http://creativecommons.org/licenses/by/4.0/

\begin{abstract}
Cancer is a disease caused by the loss of normal cell regulation and excessive proliferation. At present, there are a lot of anticancer drugs, but most of them are not ideal, with sereve side effects. Besides, during the treatment, the patients feel very bad, and they are always in great pain. Emodin is a natural anthraquinone derivative found in a variety of herbal preparations. Many studies have shown that emodin has a significant therapeutic effect on lung cancer, liver cancer, breast cancer, and so on. After reviewing a large amount of literatures, this paper summarizes the research progresses of emodin anticancer in the past five years, in order to provide theoretical basis for further development and utilization of emodin and its metabolites.
\end{abstract}

\section{Keywords}

Emodin, Antitumor Effect, Mechanism of Action, The Research Progress

\section{Introduction}

Cancer is a worldwide health problem [1] [2]. GLOBOCAN, 2020 presented up-to-date estimates of cancer incidence and mortality in late 2020. It is estimated that there were 19.3 million new cases of cancer worldwide, and 10 million people died from cancer in 2020 [3]. New cancer cases are expected to increase in the future. Asia, Latin America, the Caribbean and Africa are expected to experience relatively large increases in morbidity and mortality [4]. At present, it is very necessary to find effective anti-cancer drugs. In recent decades, phytochemicals have received more attention due to their mild side effects and reliable therapeutic effects [5]. Phytochemicals are natural products derived from herbal medicines [5]. Therefore, this paper summarizes the research progresses of emodin in anti-cancer in the past five years, hoping to provide a novel insight 
for further development of emodin, also expecting to reveal the anti-tumor potential of emodin and necessity of further studies in this field.

\section{Structure and Bioactivity of Emodin}

Emodin, a natural anthraquinone compound, is the main active biological component of rhubarb [6] [7] [8] [9]. It has a history of more than 2000 years in China [6]. Emodin (1,3,8-trihydroxy-6-methylanthraquinone, Figure 1), has been identified in Polygonum multiflorum, Cassia obtusifolia, Aloe, Rhubarb, and Polygonum cuspidatum [10] [11] [12] [13] [14], and is believed to have a variety of pharmacological effects. Emodin has a variety of biological functions, such as anti-inflammatory, anti-cancer, immunosuppressive and antiviral [7] [15] [16] [18]. Studies have shown that emodin has a significant therapeutic effect on lung cancer [19], liver cancer [20], cervical cancer [21], breast cancer [22], colon cancer [23], and so on. However, emodin is toxic to cancer cells, and may cause renal, hepatic, and reproductive toxicity, especially at high doses and during prolonged use [24].

\section{Mechanism of Anti-Tumor Activity of Emodin}

In the study of thyroid cancer, significant effects of emodin therapy were found, which was closely related to TRAF6/HIF-1 $\alpha$ /VEGF and TRAF6/CD147/MMP9 signaling pathways. Inhibition of the activation of this pathway may be one of the anti-tumor mechanisms of emodin [25]. In addition, the negative regulation of emodin on downstream signals of CCR5 may be another mechanism, which may be related to the suppressed expression of EMT-(epithelial-mesenchymal transition) and invasion-associated markers, including vimentin, snail, matrix metalloproteinase (MMP)-2 and MMP-9, and up-regulation of E-cadherin, contributing to the inhibition of invasion [22]. In studies on lung cancer cells, apoptosis of lung cancer cells was found to be related to the TRIB3/NF- $\kappa$ B pathway [19]. In addition, emodin can also reduce lipid metabolism and induce cell apoptosis through SREBP1-dependent and non-dependent pathways [26]. In colon cancer cells, the PI3K/Akt signaling pathway, another important anticancer mechanism of emodin, has been identified, which induces apoptosis and cell cycle arrest [23]. Emodin inhibitions EMT by ILK/GSK-3 $\beta$ pathway [27], and by emodin activates GSK-3 $\beta$ to inhibit ZEB1, which suppresses EMT [28] (Figure 2).

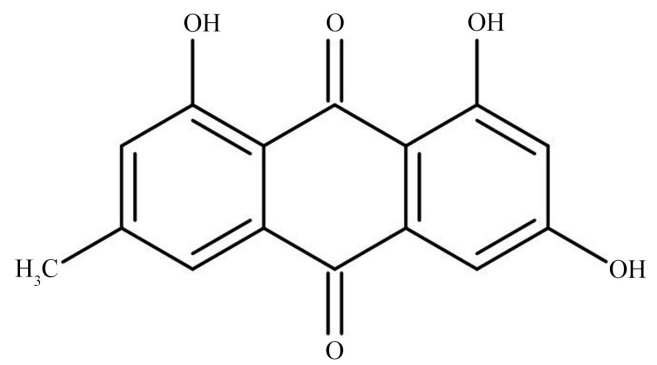

Figure 1. The structural formula of emodin. 


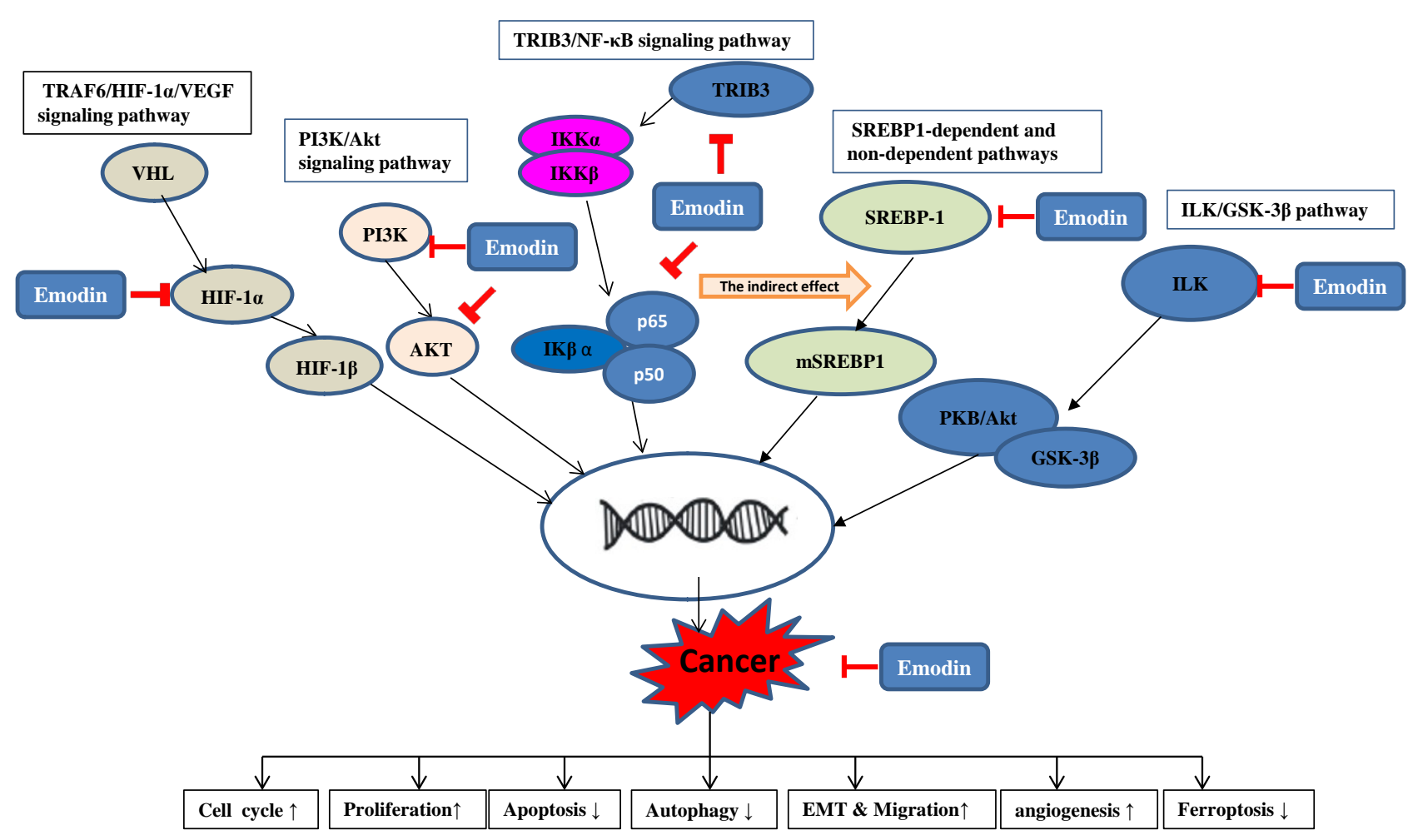

Figure 2. Antitumor mechanism of emodin.

\section{Potential Role of Emodin in Human Malignancies}

A series of studies have confirmed that the multitargeted compound emodin is minimally toxic, affordable and effective for the prevention and treatment of different types of cancers (Table 1). The following part of the review enumerates the potential anti-neoplastic actions of emodin for different cancers.

\subsection{Oral Carcinogenesis}

Oral cancer is a malignancy that accounts for $7 \%$ of new cancer cases worldwide. Incidence has increased in the past few years, especially in developing countries [29]. Emodin also has great chemoprophylaxis potential in fighting cancer [26] [27] [28] [29] [30]. Hamster buccal pouches carcinoma induced by DMBA significantly altered the status of lipid peroxidation, antioxidants, phase I and II detoxifies, and apoptotic proteins [26] [27] [28] [29] [30]. However, when emodin was administered to diseased hamsters, the status of lipid peroxidation, antioxidants, phase I and II detoxifies, and apoptotic proteins were recovered. Studies have shown that emodin can completely inhibit the formation of DMBAinduced tumors in the buccal pouches of golden Syrian hamsters [30].

\subsection{Thyroid Cancer}

Studies have shown that emodin starts to inhibit the proliferation of $8505 \mathrm{C}$ and SW1736 cells at $30 \mu \mathrm{mol} / \mathrm{l}$, and emodin can also reduce ATC angiogenesis and metastasis. After emodin treatment, it was found that the activation of TRAF6/ 
HIF-1 $\alpha$ /VEGF and TRAF6/CD147/MMP9 signaling pathways in ATC was inhibited, which is closely related to the inhibition of angiogenesis [25].

Table 1. The antitumor activity of emodin in different cancers.

\begin{tabular}{|c|c|c|c|c|}
\hline Cancer & $\begin{array}{l}\text { In Vitrol In Vivo } \\
\text { /Ex Vivo }\end{array}$ & Model/cell & Mechanism/Results & References \\
\hline $\begin{array}{l}\text { Anaplastic } \\
\text { thyroid cancer }\end{array}$ & In Vitro and In Vivo & $\begin{array}{l}8505 c, \\
\text { SW1736 }\end{array}$ & $\begin{array}{c}\downarrow \text { Proliferation } \\
\downarrow \text { Metastatic ability } \\
\downarrow \text { Angiogenesis and metastasis } \\
\text { Emodin exerts anti-angiogenic and anti-metastatic activities } \\
\text { in ATC by affecting TRAF6 mediated pathways. }\end{array}$ & [25] \\
\hline Breast cancer & In Vitro & $\begin{array}{l}\text { MDA-MB-231 } \\
\text { MDA-MB-453 }\end{array}$ & $\begin{array}{c}\text { Proliferation } \downarrow \text { Metastasis } \\
\text { Emodin inhibits adipocyte secretion of CCL5, inhibits the EMT of TNBC } \\
\text { cells, and inhibits tumor growth and lung and liver metastasis, suggesting } \\
\text { that emodin has a new role in the prevention of TNBC metastasis. }\end{array}$ & [22] \\
\hline Lung cancer & In Vitro & A549 & 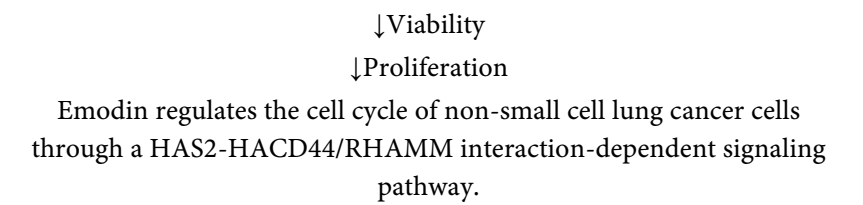 & [33] \\
\hline Lung cancer & In Vitro and In Vivo & HL-60N1 & $\begin{array}{c}\uparrow R O S, \downarrow \text { autophagy, induced apoptosis } \\
\text { Emodin selectively inhibits N2 neutrophils, thereby preventing } \\
\text { hypercoagulability and the development of lung cancer. }\end{array}$ & [34] \\
\hline lung cancer & In Vitro & $\begin{array}{c}\text { A549 } \\
\text { H1299 }\end{array}$ & 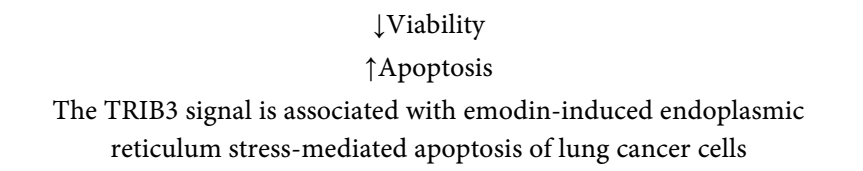 & [19] \\
\hline lung cancer & In Vitro & A549 & 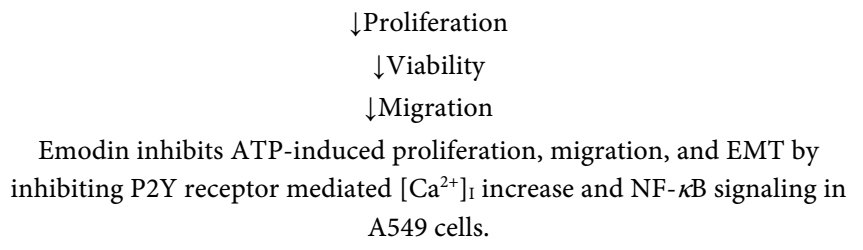 & [32] \\
\hline $\begin{array}{l}\text { Hepatocellular } \\
\text { carcinoma }\end{array}$ & In Vitro & HepG2 & $\begin{array}{c}\qquad \text { Viability } \\
\downarrow \text { Proliferation } \\
\downarrow \text { Growth } \\
859 \text { DEGs and } 5 \text { HUB genes were identified, which may be regarded as } \\
\text { the target of emodin therapy for HCC. }\end{array}$ & [20] \\
\hline $\begin{array}{l}\text { Hepatocellular } \\
\text { carcinoma }\end{array}$ & In Vitro & Bel-7402 & $\begin{array}{c}\qquad \text { Proliferation } \\
\uparrow \text { Apoptosis } \\
\downarrow \text { Viability } \\
\text { Emodin can induce apoptosis of hepatocellular carcinoma cells in SREBP } \\
\text { 1-dependent and SREBP 1-independent ways. }\end{array}$ & [26] \\
\hline $\begin{array}{l}\text { Hepatocellular } \\
\text { carcinoma }\end{array}$ & In Vitro & HepG2 & $\begin{array}{l}\uparrow \text { Apoptosis } \\
\text { Emodin induces apoptosis by up-regulation of CypD }\end{array}$ & [37] \\
\hline $\begin{array}{l}\text { Hepatocellular } \\
\text { carcinoma }\end{array}$ & In Vitro & SMMC-7721 & $\begin{array}{c}\uparrow \text { Apoptosis } \\
\downarrow \text { Proliferation } \\
\text { Emodin may be a potentially effective and safe drug to induce apoptosis } \\
\text { in HCC cells }\end{array}$ & [38] \\
\hline Colon cancer & In Vitro & $\begin{array}{l}\text { HCT116 } \\
\text { SW480 } \\
\text { SNU-C2ASNU-C5 }\end{array}$ & $\begin{array}{l}\qquad \text { Proliferation } \\
\text { Emodin provides a molecular basis for the treatment of colon cancer by } \\
\text { inhibiting FASN-mediated cell growth and apoptosis. }\end{array}$ & [40] \\
\hline
\end{tabular}




\begin{tabular}{|c|c|c|c|c|}
\hline Colon cancer & In Vitro & $\begin{array}{l}\text { HCT116 } \\
\text { LOVO }\end{array}$ & $\begin{array}{c}\qquad \begin{array}{c}\uparrow \text { Apoptosis } \\
\downarrow \text { Viability } \\
\downarrow \text { Growth }\end{array} \\
\text { Emodin induces autophagy to induce apoptosis of colon cancer cells, in } \\
\text { which the production of reactive oxygen species is the key }\end{array}$ & [39] \\
\hline Colon cancer & In Vitro & CACO-2 & $\begin{array}{c}\downarrow \text { Proliferation } \\
\uparrow \text { Apoptosis } \\
\text { Emodin has shown effective anticancer effects in Caco-2 human colon } \\
\text { cancer cells by inducing apoptosis, cell cycle arrest and inhibiting } \\
\text { PI3K/Akt signaling pathway. }\end{array}$ & [23] \\
\hline Cervical cancer & In Vitro & $\mathrm{HeLa}$ & 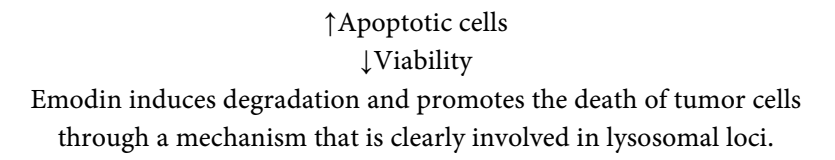 & [21] \\
\hline Cervical cancer & In Vitro & HeLa celIs & $\begin{array}{c}\uparrow \text { Apoptotic } \\
\downarrow \text { Viability } \\
\text { Emodin causes cervical cancer cell death by inducing } \\
\text { mitotic catastrophes }\end{array}$ & [41] \\
\hline Ovarian cancer & In Vitro & $\begin{array}{c}\text { A2780 } \\
\text { SK-OV-3 }\end{array}$ & $\begin{array}{c}\downarrow \text { Proliferation } \\
\downarrow \text { Migration } \\
\downarrow \text { Invasion } \\
\downarrow \text { EMT } \\
\text { Emodin inhibits EMT in EOC cells through ILK/GSK-3 } \beta / \text { slug } \\
\text { signaling pathway. }\end{array}$ & [27] \\
\hline Ovarian cancer & In Vitro & $\begin{array}{c}\text { A2780 } \\
\text { SK-OV-3 }\end{array}$ & $\begin{array}{l}\qquad \text { Invasion } \\
\downarrow \text { EMT } \\
\text { In Vitro, EMO inhibited epithelial ovarian cancer cell invasion by } \\
\text { regulating the GSK- } 3 \beta / \beta \text {-catenin /ZEB1 signaling pathway. }\end{array}$ & [28] \\
\hline
\end{tabular}

\subsection{Breast Cancer}

Breast cancer has overtaken lung cancer as the most commonly diagnosed cancer in women for the first time, according to the latest cancer statistics [3] [4]. Compared with epirubicin, emodin can inhibit the proliferation and metastasis of TNBC cells more effectively under the condition of rich adipocytes. Studies have shown that emodin may inhibit the proliferation and invasion of tumor necrosis factor-related apoptotic cells by partially down-regulating the secretion of CCL5. Besides, the inhibition of TNBC invasion and migration was found to be related to the negative regulation of downstream signaling pathways of CCR5 and EMT-related markers by emodin. Nude mice fed a high-fat, high-sugar diet were inoculated with TNBC cells in fat pads 20 days later. After 7 days, mice were treated with $40 \mathrm{mg} / \mathrm{mL}$ of emodin oral solution for 21 consecutive days, which showed that emodin down-regulated $\mathrm{CCl} 5$ levels, suggesting that emodin inhibited tumor cell growth and metastasis of TNBC by reducing serum CCL5 levels in mice fed a high-fat, high-sugar diet [22].

\subsection{Lung Cancer}

In 2020, lung cancer caused the largest number of death among men and the second largest number among women. In recent years, the death rate from lung cancer has been declining in most high-income developed countries, but many 
low-income countries still have high death rates from lung cancer [31]. Therefore, it is particularly important to study more new drugs for the treatment of lung cancer. A large number of studies have shown that emodin can treat lung cancer by inhibiting cell viability, regulating cell cycle, and inhibiting cell proliferation and migration [19] [32] [33]. This makes sense for clinical applications. Some studies show that emodin at $30 \mu \mathrm{M}$ suppressed the viability of A549, which has to do with cell cycle regulation [33]. Emodin can reduce the expression of cyclins $\mathrm{A}$ and $\mathrm{B}$, and increase the expression of cyclins $\mathrm{C}, \mathrm{D}$, and $\mathrm{E}$, thus increasing the number of cells in $G_{1} / G_{0}$ phase, and decreasing the number of cells in $S$ and $G_{2} / M$ phase, and finally achieving the effect of regulating cell cycle to inhibit the proliferation of lung cancer cells [33]. Besides, studies have shown that the apoptosis of lung cancer cells induced by endoplasmic reticulum stress-induced by emodin is related to the TRIB3/NF- $\kappa$ B pathway. To prove whether Trib3 regulates emodin-induced apoptosis of A549 and H1299 cells, the changes before and after knocking out TRIB3 were compared in several experiments, respectively. The results showed that emodin-induced apoptosis of lung cancer cells was closely related to TRIB3 [19]. In addition to regulating cell apoptosis and cell cycle, emodin also has an inhibitory effect on cell migration [32]. These three experiments strongly prove that emodin has a significant effect on the treatment of lung cancer. In a Urethane-induced lung carcinogenesis model of one study, emodin was found to prevent Urethane-induced lung cancer by selectively inhibiting N2 neutrophils [34]. In addition to the direct role of emodin in the treatment of lung cancer, it can also play a good indirect role in the treatment of lung cancer. Emodin has been found to have a significant synergistic effect when used in combination with some drugs for lung cancer that do not work well because of new drug resistance [35] [36].

\subsection{Liver Cancer}

Currently, early HCC can be treated with liver transplantation and surgical resection, but treatment options for late HCC are very limited, so more treatments need to be found. After treating with emodin for $72 \mathrm{~h}$, the growth of HCC cells was significantly inhibited. To investigate the mechanism of emotion, action, DEGs, and hub genes were identified, and it was found that DEGs were involved in emotion-mediated proliferation inhibition of liver cancer [20].

HCC cells Bel-7402 were treated with emodin at different concentrations for 12,24 , and $48 \mathrm{~h}$, and cell viability was detected by MTT assay. It was found that emodin significantly reduced cell viability in a dose-dependent and time-dependent manner in Bel-7402 cells. After treatment with emodin $(100 \mu \mathrm{mol} / \mathrm{L})$ for $24 \mathrm{~h}$, apoptosis of BEL-7402 cells was increased significantly. Finally, emodin was found to reduce lipid metabolism and induce apoptosis through SREBP1-dependent and non-dependent pathways [26]. CyPD plays an important role in the induction of apoptosis of HepG2 cells by emodin [37]. It has also been shown that emodin inhibits the proliferation and activity of SMMC-7721 cells, and also induces apoptosis [38]. When the concentration of emodin increased from 10 to 
$200 \mathrm{~mol} / \mathrm{L}$, the viability of SMMC-7721 cells decreased significantly [38].

\subsection{Colon Cancer}

Colon cancer is the third most common cancer worldwide. After emodin treatment, the growth and activity of colon cancer cells were inhibited, and emodin also induced the apoptosis of HCT116 and LoVo cells. Apoptosis was found to be related to autophagy induced by emodin. The accumulation of ROS in colon cancer cells was increased after emodin treatment, which promoted autophagy and apoptosis [39]. HCT116 has treated with 25 and $50 \mu \mathrm{M}$ emodin, and the proliferation of HCT116 cells was significantly inhibited by $30.4 \%$ and $24.2 \%$, respectively. This is related to the inhibition of FASN protein level by emodin in HCT116 cells, and further studies show that the degradation of FASN protein induced by emodin is caused by the increase of protein ubiquitination activity [40]. At 60 micron concentration, the apoptotic cell population of CACO-2 significantly increased from $1.85 \%$ to $42.66 \%$ in the control group, and the apoptosis induced by emodin followed the mitochondrial pathway. In the study of CACO-2, it was found that emodin can inhibit cell proliferation and PI3K/ AKT signaling pathway, and also induce cell apoptosis and cell cycle arrest, which has a good anti-cancer effect on colon cancer cells [23].

\subsection{Ovarian Cancer}

The proliferation, migration, and invasion of A2780 and SK-OV-3 Cells treated with emodin for $48 \mathrm{~h}$ were significantly reduced, which has found a link with Slug [27]. From the past five years of research, it is known that emodin inhibits EMT by two pathways, one is the ILK/GSK-3 $\beta$ pathway [27], and the other is that emodin activates GSK-3 $\beta$ to inhibit ZEB1, which can inhibit EMT [28].

\subsection{Cervical Cancer}

Emodin can promote the death of cervical cancer cells through lysosomal-induced degradation [21]. With the increase of emodin concentration, the degradation process increased and the cell activity decreased [21]. The lysosome system was significantly activated at the concentration of emodin in the range of $15-30 \mu \mathrm{M}$, while few lysosomes and vacuoles and a large number of apoptotic cells could be seen at $100 \mu \mathrm{M}$ [21]. Besides, emodin can also increase the membrane permeability of lysosomes, decrease the activities of cathepsin D and L in lysosomes, and increase the activity of proteolytic enzymes [21]. There are also research findings that emodin can make cervical cancer cell cycle disorder and apoptosis increase [41]. This is mainly due to the inhibition of mitotic activity by emodin. The inhibitory effect of emodin on cell division was highest at $100 \mu \mathrm{M}$. Besides, emodin can also damage the cytoskeleton [41].

\section{Summary and Perspectives}

In conclusion, emodin has significant anti-cancer effects. Emodin mainly inhibits the proliferation and cell viability of cancer cells and induces cell apoptosis. 
So emodin is still worth studying. The anti-cancer potential of emodin is great. Although emodin has anti-cancer effects in many cancers, its underlying molecular mechanisms remain to be elucidated [27]. In addition, poor water solubility of emodin increases the difficulty of drug development and researches [42]. Further research on emodin is needed to maximize its clinical use (Table 2).

Table 2. Acronyms.

\begin{tabular}{|c|c|}
\hline LDH & Lactic dehydrogenase \\
\hline VEGF & Vascular endothelial growth factor \\
\hline$N F-\kappa B$ & Nuclear factor kappa B \\
\hline $\mathrm{PCa}$ & Prostatic cancer \\
\hline KLF6 & Kruppel-like factor 6 \\
\hline Bcl-2 & B-cell lymphoma-2 \\
\hline ROS & Reactive oxygen species \\
\hline MMP-2 & Matrix Metalloproteinase-2 \\
\hline RCC & Renal cell carcinoma \\
\hline HCC & Hepatocellular Carcinoma \\
\hline MVA pathway & Mevalonate pathway \\
\hline TCTP & Translation-controlled tumor protein \\
\hline PCD & Programmed cell death \\
\hline IL-10 & Interleukin-10 \\
\hline NF- $\kappa \mathrm{B}$ & Nuclear factor $\kappa \mathrm{B}$ \\
\hline IL- $1 \beta$ & Interleukin $1 \beta$ \\
\hline $\mathrm{COX}-2$ & Cyclooxygenase- 2 \\
\hline NSCLC & Non-small cell lung cancer \\
\hline EMT & Epidermal interstitial transformation \\
\hline ESCC & Esophageal squamous cell carcinoma \\
\hline ATC & Anaplastic thyroid carcinoma \\
\hline mTOR & Mammalian target of rapamycin \\
\hline $\mathrm{HNC}$ & Head and neck cancer \\
\hline API & Active pharmaceutical ingredient \\
\hline $\mathrm{PCa}$ & Prostate cancer \\
\hline $\mathrm{AR}$ & Androgen receptor \\
\hline NF1 & Neurofibromatosis type 1 \\
\hline MPNST & Malignant peripheral nerve sheath tumors \\
\hline FIGO & International Federation of Gynecology and Obstetrics \\
\hline EC & Esophageal cancer \\
\hline $\mathrm{ADM}$ & Doxorubicin \\
\hline
\end{tabular}




\section{Conflicts of Interest}

The authors declare no conflicts of interest regarding the publication of this paper.

\section{References}

[1] Siegel, R.L., Miller, K.D. and Jemal, A. (2020) Cancer Statistics, 2020. CA: A Cancer Journal for Clinicians, 70, 7-30. https://doi.org/10.3322/caac.21590

[2] Siegel, R.L., Miller, K.D., Fuchs, H.E. and Jemal, A. (2021) Cancer Statistics, 2021. CA: A Cancer Journal for Clinicians, 71, 7-33. https://doi.org/10.3322/caac.21654

[3] Sung, H., Ferlay, J., Siegel, R.L., Laversanne, M., Soerjomataram, I., Jemal, A. and Bray, F. (2021) Global Cancer Statistics 2020: GLOBOCAN Estimates of Incidence and Mortality Worldwide for 36 Cancers in 185 Countries. CA: A Cancer Journal for Clinicians, 68, 394-424. https://doi.org/10.3322/caac.21660

[4] Cao, W., Chen, H.-D., Yu, Y.-W., Li, N. and Chen, W.-Q. (2021) Changing Profiles of Cancer Burden Worldwide and in China: A Secondary Analysis of the Global Cancer Statistics 2020. Chinese Medical Journal, 134, 783-791. https://doi.org/10.1097/CM9.0000000000001474

[5] Arumuggam, N., Bhowmick, N.A. and Rupasinghe, H.P. (2015) A Review: Phytochemicals Targeting JAK/STAT Signaling and IDO Expression in Cancer. Phytotherapy Research, 29, 805-817. https://doi.org/10.1002/ptr.5327

[6] Dong, X., Fu, J., Yin, X., Cao, S., Li, X., Lin, L., Hu, Y. and Ni, J. (2016) Emodin: A Review of Its Pharmacology, Toxicity and Pharmacokinetics. Phytotherapy Research, 30, 1207-1218. https://doi.org/10.1002/ptr.5631

[7] Ye, B., Chen, X., Dai, S., Han, J., Liang, X., Lin, S., Cai, X., Huang, Z. and Huang, W. (2019) Emodin Alleviates Myocardial Ischemia/Reperfusion Injury by Inhibiting Gasdermin D-Mediated Pyroptosis in Cardiomyocytes. Drug Design, Development and Therapy, 13, 975-990. https://doi.org/10.2147/DDDT.S195412

[8] Ma, C., Wen, B., Zhang, Q., Shao, P., Gu, W., Qu, K., Shi, Y., Wang, B. (2019) Emodin Induces Apoptosis and Autophagy of Fibroblasts Obtained from Patient with Ankylosing Spondylitis. Drug Design, Development and Therapy, 13, 601-609. https://doi.org/10.2147/DDDT.S182087

[9] Zhang, Q., et al. (2019) Emodin Attenuated Severe Acute Pancreatitis via the P2X Ligand-Gated Ion Channel 7/NOD-Like Receptor Protein 3 Signaling Pathway. Oncology Reports, 41, 270-278.

[10] Lee, M.H., Kao, L. and Lin, C.C. (2011) Comparison of the Antioxidant and Transmembrane Permeative Activities of the Different Polygonum cuspidatum Extracts in Phospholipid-Based Microemulsions. Journal of Agricultural and Food Chemistry, 59, 9135-9141. https://doi.org/10.1021/jf201577f

[11] Yang, Y.C., Lim, M.Y. and Lee, H.S. (2003) Emodin Isolated from Cassia obtusifolia (Leguminosae) Seed Shows Larvicidal Activity against Three Mosquito Species. Journal of Agricultural and Food Chemistry, 51, 7629-7631. https://doi.org/10.1021/jf034727t

[12] Naqvi, S., Ullah, M.F. and Hadi, S.M. (2010) DNA Degradation by Aqueous Extract of Aloe vera in the Presence of Copper Ions. Indian Journal of Biochemistry and Biophysics, 47, 161-165.

[13] Wang, J.B., Zhao, H.-P., Zhao, Y.-L., Jin, C., Liu, D.-J., Kong, W.-J., et al. (2011) Hepatotoxicity or Hepatoprotection? Pattern Recognition for the Paradoxical Effect of the Chinese Herb Rheum palmatum L. in Treating Rat Liver Injury. PLoS ONE, 
6, e24498. https://doi.org/10.1371/journal.pone.0024498

[14] Wang, M., Zhao, R., Wang, W., Mao, X. and Yu, J. (2012) Lipid Regulation Effects of Polygoni Multiflori Radix, Its Processed Products and Its Major Substances on Steatosis Human Liver Cell Line L02. Journal of Ethnopharmacology, 139, 287-293. https://doi.org/10.1016/j.jep.2011.11.022

[15] Srinivas, G., Babykutty, S., Sathiadevan, P.P. and Srinivas, P. (2007) Molecular Mechanism of Emodin Action: Transition from Laxative Ingredient to an Antitumor Agent. Medicinal Research Reviews, 27, 591-608.

https://doi.org/10.1002/med.20095

[16] Kuo, Y.C., Meng, H.C. and Tsai, W.J. (2001) Regulation of Cell Proliferation, Inflammatory Cytokine Production and Calcium Mobilization in Primary Human T Lymphocytes by Emodin from Polygonum hypoleucum Ohwi. Inflammation Research, 50, 73-82. https://doi.org/10.1007/s000110050727

[17] Li, J., Ding, L., Song, B., Xiao, X., Qi, M., et al. (2016) Emodin Improves Lipid and Glucose Metabolism in High Fat Diet-Induced Obese Mice through Regulating SREBP Pathway. European Journal of Pharmacology, 770, 99-109. https://doi.org/10.1016/j.ejphar.2015.11.045

[18] Yu, L., Gong, L., Wang, C., Hu, N., Tang, Y., Zheng, L., Dai, X. and Li, Y. (2020) Radix Polygoni Multiflori and Its Main Component Emodin Attenuate Non-Alcoholic Fatty Liver Disease in Zebrafish by Regulation of AMPK Signaling Pathway. Drug Design, Development and Therapy, 14, 1493-1506. https://doi.org/10.2147/DDDT.S243893

[19] Su, J., Yan, Y., Qu, J., Xue, X., Liu, Z. and Cai, H. (2017) Emodin Induces Apoptosis of Lung Cancer Cells through ER Stress and the TRIB3/NF- $\kappa$ B Pathway. Oncology Reports, 37, 1565-1572. https://doi.org/10.3892/or.2017.5428

[20] Zhou, R.S., Wang, X.-W., Sun, Q.-F., Ye, Z.J., Liu, J.-W., Zhou, D.-H. and Tang, Y. (2019) Anticancer Effects of Emodin on HepG2 Cell: Evidence from Bioinformatic Analysis. BioMed Research International, 2019, Article ID: 3065818. https://doi.org/10.1155/2019/3065818

[21] Trybus, W., Król, T., Trybus, E., Kopacz-Bednarska, A., Król, G. and Karpowicz, E. (2017) Changes in the Lysosomal System of Cervical Cancer Cells Induced by Emodin Action. Anticancer Research, 37, 6087-6096. https://doi.org/10.21873/anticanres.12057

[22] Song, X., et al. (2018) Emodin Inhibits Epithelial-Mesenchymal Transition and Metastasis of Triple Negative Breast Cancer via Antagonism of CC-Chemokine Ligand 5 Secreted from Adipocytes. International Journal of Molecular Medicine, 42, 579-588.

[23] Ma, Q., et al. (2018) Antitumor Effects of Emodin in CACO-2 Human Colon Carcinoma Cells Are Mediated via Apoptosis, Cell Cycle Arrest and Downregulation of PI3K/AKT Signalling Pathway. Journal of B.U.ON., 23, 587-591.

[24] Akkol, E.K., Tatlı, I.I., Karatoprak, G.Ş., Ağar, O.T., Yücel, Ç., Sobarzo-Sánchez, E. and Capasso, R. (2021) Is Emodin with Anticancer Effects Completely Innocent? Two Sides of the Coin. Cancers, 13, 2733. https://doi.org/10.3390/cancers13112733

[25] Shi, G.H. and Zhou, L. (2018) Emodin Suppresses Angiogenesis and Metastasis in Anaplastic Thyroid Cancer by Affecting TRAF6-Mediated Pathways in Vivo and in Vitro. Molecular Medicine Reports, 18, 5191-5197.

[26] Yang, N., Li, C., Li, H., Liu, M., Cai, X., Cao, F., Feng, Y., Li, M. and Wang, X. (2019) Emodin Induced SREBP1-Dependent and SREBP1-Independent Apoptosis in Hepatocellular Carcinoma Cells. Frontiers in Pharmacology, 10, 709. https://doi.org/10.3389/fphar.2019.00709 
[27] Lu, J., Tong, Z., Ding, Y., Liu, J., Pan, Y., Cao, L., Tu, J., Wang, Y., Liu, G. and Li, W. (2016) Emodin Inhibits the Epithelial to Mesenchymal Transition of Epithelial Ovarian Cancer Cells via ILK/GSK-3 $\beta$ /Slug Signaling Pathway. BioMed Research International, 2016, Article ID: 6253280. https://doi.org/10.1155/2016/6089430

[28] Hu, C., Dong, T., Li, R., Lu, J., Wei, X. and Liu, P. (2016) Emodin Inhibits Epithelial to Mesenchymal Transition in Epithelial Ovarian Cancer Cells by Regulation of GSK-3 $\beta / \beta$-Catenin/ZEB1 Signaling Pathway. Oncology Reports, 35, 2027-2034. https://doi.org/10.3892/or.2016.4591

[29] Ge, S., Zhou, H., Zhou, Z., Lin, L. and Lou, J. (2021) Serum Metabolite Profiling of a 4-Nitroquinoline-1-oxide-Induced Experimental Oral Carcinogenesis Model Using Gas Chromatography-Mass Spectrometry. PeerJ-Life \& Envitonment, 9, e10619. https://doi.org/10.7717/peerj.10619

[30] Manimaran, A. and Manoharan, S. (2018) Tumor Preventive Efficacy of Emodin in 7,12-Dimethylbenz[a]Anthracene-Induced Oral Carcinogenesis: A Histopathological and Biochemical Approach. Pathology Oncology Research: POR, 24, 19-29. https://doi.org/10.1007/s12253-017-0205-7

[31] Torre, L.A., Siegel, R.L. and Jemal, A. (2016) Lung Cancer Statistics. Advances in Experimental Medicine and Biology, 893, 1-19. https://doi.org/10.1007/978-3-319-24223-1_1

[32] Wang, X., Li, L., Guan, R., Zhu, D., Song, N. and Shen, L. (2017) Emodin Inhibits ATP-Induced Proliferation and Migration by Suppressing P2Y Receptors in Human Lung Adenocarcinoma Cells. Cellular Physiology and Biochemistry. International Journal of Experimental Cellular Physiology, Biochemistry, and Pharmacology, 44, 1337-1351. https://doi.org/10.1159/000485495

[33] Li, M., Jin, S., Cao, Y., Xu, J., Zhu, S. and Li, Z. (2021) Emodin Regulates Cell Cycle of Non-Small Lung Cancer (NSCLC) Cells through Hyaluronan Synthase 2 (HA2)HA-CD44/Receptor for Hyaluronic Acid-Mediated Motility (RHAMM) Interaction-Dependent Signaling Pathway. Cancer Cell International, 21, 19.

https://doi.org/10.1186/s12935-020-01711-Z

[34] Li, Z., Lin, Y., Zhang, S., Zhou, L., Yan, G., Wang, Y., et al. (2019) Emodin Regulates Neutrophil Phenotypes to Prevent Hypercoagulation and Lung Carcinogenesis. Journal of Translational Medicine, 17, 90.

https://doi.org/10.1186/s12967-019-1838-y

[35] Iyer, V.V., Priya, P.Y. and Kangeyavelu, J. (2018) Effects of Increased Accumulation of Doxorubicin Due to Emodin on Efflux Transporter and LRP1 Expression in Lung Adenocarcinoma and Colorectal Carcinoma Cells. Molecular and Cellular Biochemistry, 449, 91-104. https://doi.org/10.1007/s11010-018-3346-4

[36] Hintzpeter, J., Seliger, J.M., Hofman, J., Martin, H.-J., Wsol, V. and Maser, E. (2016) Inhibition of Human Anthracycline Reductases by Emodin-A Possible Remedy for Anthracycline Resistance. Toxicology and Applied Pharmacology, 293, 21-29. https://doi.org/10.1016/j.taap.2016.01.003

[37] Zhang, L., He, D., Li, K., Liu, H., Wang, B., Zheng, L. and Li, J. (2017) Emodin Targets Mitochondrial Cyclophilin D to Induce Apoptosis in HepG2 Cells. Biomedicine \& Pharmacotherapy, 90, 222-228. https://doi.org/10.1016/j.biopha.2017.03.046

[38] Lin, W., Zhong. M., Yin, H., Chen, Y., Cao, Q., Wang, C. and Ling, C. (2016) Emodin Induces Hepatocellular Carcinoma Cell Apoptosis through MAPK and PI3K/AKT Signaling Pathways in Vitro and in Vivo. Oncology Reports, 36, 961-967. https://doi.org/10.3892/or.2016.4861

[39] Wang, Y., Luo, Q., He, X., Wei, H., Wang, T., Shao, J. and Jiang, X. (2018) Emodin 
Induces Apoptosis of Colon Cancer Cells via Induction of Autophagy in a ROSDependent Manner. Oncology Research, 26, 889-899. https://doi.org/10.3727/096504017X15009419625178

[40] Lee, K.H., Lee, M.S., Cha, E.Y., Sul, J.Y., Lee, J.S., Kim, J.S., Park, J.B. and Kim, J.Y. (2017) Inhibitory Effect of Emodin on Fatty Acid Synthase, Colon Cancer Proliferation and Apoptosis. Molecular Medicine Reports, 15, 2163-2173. https://doi.org/10.3892/mmr.2017.6254

[41] Trybus, W., Król, T., Trybus, E., Stachurska, A., Król, G. and Kopacz-Bednarska, A. (2019) Emodin Induces Death in Human Cervical Cancer Cells Through Mitotic Catastrophe. Anticancer Research, 39, 679-686. https://doi.org/10.21873/anticanres.13163

[42] Park, B., Yoon, W., Yun, J., Ban, E., Yun, H. and Kim, A. (2019) Emodin-Nicotinamide (1:2) Cocrystal Identified by Thermal Screening to Improve Emodin Solubility. International Journal of Pharmaceutics, 557, 26-35.

https://doi.org/10.1016/j.ijpharm.2018.12.027 